\title{
Influence of Splenectomy upon Cerebral Excitability in Rabbits \\ (Preliminary Report)
}

By

\author{
Takashi Mizuno, Sei-ichiro Sasaki, Toshihiro \\ Okamura and Tsuneo Arakawa \\ From the Department of Pediatrics, Faculty of Medicine, Tohoku \\ University, Sendai, Director: Prof. Ts. Arakawa
}

(Received for publication, June 7, 1962)

A possible relationship between spleen and cerebral excitability has been suspected by one of the authors (Ts. Arakawa) who had experienced an infantile case with a complete disappearance of myoclonic fits after repeated irradiation of X-ray upon the splenic region.

The aim of the present investigation was to determine whether or not splenectomy would bring about any influence upon electrical activity of the cerebral structures in rabbits, especially upon 'the threshold' of the cortex, thalamus and rhinencephalon.

For evaluating the excitability of the stimulated structures, the liminal voltage necessary to induce a self-sustained after-discharge - 'the threshold' of the after-discharge — was used." The electrodes for giving strictly localized stimulation as well as for recording the electrical responses induced by the stimulation were implanted into the cortex, thalamus and ventral rhinencephalon according to the procedure of Gangloff et al. ${ }^{11}$ The electrical stimulation was given for 10 seconds by using a stimulator, Es-103 Type, San-ei-sokki. The electrical stimulus consisted of 40 impulses per second and each of the impulse was of the duration of $1.0 \mathrm{msec}$. The splenectomy was carried out about 40 days prior to this experimentation and these splenectomized rabbits were living in good health.

The results obtained were summarized as follows (cf. Table I):

1) The cortical threshold showed no significant difference between the splenectomized rabbits and the control.

2) The thalamic threshold was elevated significantly in the splenectomized rabbits as compared with that of the control.

3) The ventral rhinencephalic threshold was significantly decreased by the splenectomy.

水野 隆, 佐々木静一郎, 岡村敏弘, 荒川雅男 
TABLE I. The Influence of Splenectomy on the Threshold in Volts of the Cerebral Excitability in Rabbits.

\begin{tabular}{|c|c|c|c|c|}
\hline & $\begin{array}{l}\text { No. of } \\
\text { rabbits }\end{array}$ & $\begin{array}{l}\text { Cortical thre- } \\
\text { shold in volts }\end{array}$ & $\begin{array}{l}\text { Thalamic thre- } \\
\text { shold in volts }\end{array}$ & $\begin{array}{l}\text { Ventral rhinencephalie } \\
\text { threshold in volts }\end{array}$ \\
\hline \multirow[t]{2}{*}{ 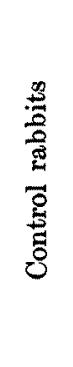 } & $\begin{array}{r}1 \\
2 \\
3 \\
4 \\
5 \\
6 \\
7 \\
8 \\
9 \\
10\end{array}$ & $\begin{array}{r}13.0 \\
6.5 \\
2.5 \\
7.0 \\
6.5 \\
5.5 \\
10.0 \\
7.0 \\
6.0 \\
4.0\end{array}$ & $\begin{array}{l}4.0 \\
2.0 \\
1.5 \\
2.5 \\
3.0 \\
3.0 \\
3.5 \\
4.0 \\
4.0 \\
4.0\end{array}$ & $\begin{array}{l}5.0 \\
6.5 \\
6.0 \\
2.5 \\
5.5 \\
4.0 \\
7.0 \\
6.0 \\
4.5 \\
4.0\end{array}$ \\
\hline & $\begin{array}{c}\text { Average } \\
\pm \underset{\text { Standard }}{\text { deviation }}\end{array}$ & $\begin{array}{r}6.8 \\
\pm \quad 2.9\end{array}$ & $\begin{array}{r}3.1 \\
\pm 0.2\end{array}$ & $\begin{array}{r}5.1 \\
\pm \quad 1.3\end{array}$ \\
\hline \multirow[t]{2}{*}{ 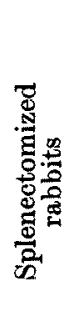 } & $\begin{array}{l}1 \\
2 \\
3 \\
4 \\
5 \\
6 \\
7 \\
7 \\
8 \\
9\end{array}$ & $\begin{array}{r}5.5 \\
7.0 \\
5.0 \\
2.0 \\
9.5 \\
5.5 \\
10.5 \\
2.5 \\
6.0\end{array}$ & $\begin{array}{l}6.0 \\
5.0 \\
5.5 \\
3.5 \\
4.0 \\
4.0 \\
6.0 \\
2.0 \\
3.5\end{array}$ & $\begin{array}{l}2.5 \\
2.5 \\
2.0 \\
3.5 \\
2.0 \\
3.5 \\
4.5 \\
3.0 \\
8.0\end{array}$ \\
\hline & $\begin{array}{c}\text { Average } \\
\pm \text { Standard } \\
\text { deviation }\end{array}$ & $\begin{array}{r}5.9 \\
+\quad 2.8\end{array}$ & $\begin{array}{r}4.3 \\
\pm 1.7\end{array}$ & $\begin{array}{r}3.5 \\
\pm \quad 1.8\end{array}$ \\
\hline
\end{tabular}

\section{CONCLUSIONS}

Splenectomy gave a profound influence upon cerebral excitability of rabbits - an elevation of the thalamic threshold and a decrease of the ventral rhinencephalic threshold.

\section{References}

1) Gangloff, H. \& Monnier, M., Electroencephalography and Clin. Neurophysiol., 1957, 9, 43. 